\title{
RADIOTHERAPY IN ARTHRITIS*
}

\author{
BY \\ M. H. L. DESMARAIS \\ From the Rheumatism Research Unit of the South West and Oxford Regions, \\ Royal National Hospital for Rheumatic Diseases, Bath
}

(RECEIVED FOR PUbliCATION JANUARY 15, 1953)

Since the discovery of $x$ rays by Roentgen in 1895 we have witnessed great advances in their application to diagnosis and therapy. In the field of therapy the main effort has been directed towards the cure of malignant diseases, but in the literature we find that this agent has also been applied for many years to the treatment of non-malignant conditions.

Sokolow (1897) and Stenbeck (1898) were the first to use $x$ rays in the treatment of joint diseases. Since then many encouraging but conflicting reports regarding the value of $x$ rays in different arthritic conditions have been published, but most of these, except for those of Smyth and others (1941) and Kuhns and Morrison (1946), were not based on carefully controlled experiments. The various authors agreed about the beneficial effects of $x$ rays in ankylosing spondylitis and osteo-arthritis, but they were not in agreement regarding their results in rheumatoid arthritis. Smyth stated that in rheumatoid arthritis the results were unpredictable and unreliable, and in general, so discouraging that this form of treatment was abandoned altogether, except in rare and obstinate cases in which a psychic effect was desirable. Kuhns and Morrison, on the other hand, in a small controlled series, reported an improvement in 79 per cent. of their rheumatoid cases.

The present work was prompted by these conflicting reports, and a clinical experiment was planned and carried out under strictly controlled conditions in order to assess the value of different dosages of $x$ rays in osteo-arthritis, rheumatoid arthritis, and ankylosing spondylitis.

\section{Methods}

Accordingly, cases coming under treatment were allocated to different dosage groups by random sampling, and treated either by low voltage therapy (L.V.T.) or by high voltage therapy (H.V.T.), using small doses (A),

* Paper delivered at the Annual General Meeting of the Heberden Society on December 5, 1952. medium doses (B), or large doses (C). In addition, a control group was included in which the current was not switched on. Table I shows the doses used for the various joints treated. A small selected group in which strict random sampling was not possible was also followed-up.

TABLE I

DOSAGES AND SITES

\begin{tabular}{|c|c|c|c|c|c|c|c|}
\hline \multirow{2}{*}{\multicolumn{3}{|c|}{ Site }} & \multicolumn{3}{|c|}{ High Voltage Therapy } & \multirow{2}{*}{$\begin{array}{l}\text { Low } \\
\text { Voltage } \\
\text { Therapy }\end{array}$} & \multirow{2}{*}{ Control } \\
\hline & & & $\mathbf{A}$ & B & C & & \\
\hline $\begin{array}{l}\text { Spine } \\
\text { Hip }\end{array}$ & $\cdots$ & $\cdots$ & 500 & 1,000 & $\begin{array}{l}1,500 \\
2,000\end{array}$ & 300 & Nil \\
\hline $\left.\begin{array}{l}\text { Knee } \\
\text { Ankle }\end{array}\right\} \ldots$ & . & $\cdots$ & 500 & 750 & 1,000 & - & Nil \\
\hline Elbow .. & $\cdots$ & $\cdots$ & 500 & 600 & 800 & - & Nil \\
\hline $\left.\begin{array}{l}\text { Wrist } \\
\text { Tarsus }\end{array}\right\} \ldots$ & $\ldots$ & $\ldots$ & 300 & 400 & 500 & - & Nil \\
\hline \multicolumn{3}{|c|}{ Interphalangeal Joints } & 100 & 200 & 300 & - & $\mathrm{Nil}$ \\
\hline
\end{tabular}

The dose for the spine was measured in skin units and for the other joints in mid-joint units. All cases received physiotherapy as indicated. In this report the unselected and selected cases have been grouped together, as it was found that the results obtained in the two groups were very similar. Most of the patients were followed-up and reassessed clinically, 6 weeks, 3 months, 6 months, and one year after treatment. In this paper, however, the main results discussed are confined, for brevity, to the 3-month period only.

The change in the degree of pain as reported by the patient was the main factor used in the assessments. The alteration in the range of movement, swelling, and tenderness, and any improvement in function were also noted. The sedimentation rate, haemoglobin count, weight, and radiological examinations were repeated at frequent intervals during the follow-up. The clinical improvement in the degree of pain after treatment was recorded as "nil", "slight", or "marked". All the assessments were made by the same observer using the same criteria of improvement throughout.

The physical factors of H.V.T. were $220 \mathrm{kV}, 15 \mathrm{~mA}$, half-value layer (H.V.L.) $1.5 \mathrm{~mm}$. Cu, and focal skin distance (F.S.D.) $50 \mathrm{~cm}$. The filters used were made of $1 \mathrm{~mm}$. Cu, and $1 \mathrm{~mm}$. Al. The size of the field varied with 
the areas treated. Treatment was given twice weekly for 3 or 4 weeks to all areas except the spine. In the case of the larger joints the total weekly mid-joint doses of $250 \mathrm{r}$ was never exceeded. For the smaller joints the total dose was always fractionated and the treatment extended over 3 weeks. The spine and the sacro-iliac joints were divided into five fields and each field was treated twice weekly with an average dose of 300 skin $r$ per week. On this programme the course lasted between 4 to 6 weeks. In the young female patients, glancing fields were used to irradiate the sacro-iliac joints.

The physical factors of L.V.T. were $140 \mathrm{kV}, 5 \mathrm{~mA}$, H.V.L. $7 \cdot 5 \mathrm{~mm}$. Al, F.S.D. $25 \mathrm{~cm}$, and filters of 0.25 $\mathrm{mm}$. $\mathrm{Cu}$, and $1 \mathrm{~mm}$. Al.

The trunk was irradiated through a strip $10 \mathrm{~cm}$. wide over the spine and $15 \times 15 \mathrm{~cm}$. over the sacrum and sacro-iliac joints. The whole trunk was given 50 skin $r$ twice weekly for three weeks to a total dose of 300 skin $r$.

For the controls the same routine was used as for the cases treated by H.V.T., but the current was switched off.

\section{Material}

In the present series 788 cases were treated. These consisted of 429 cases of osteo-arthritis, 257 cases of rheumatoid arthritis, and 102 cases of ankylosing spondylitis.

\section{Results}

Osteo-Arthritis. The results obtained in the 429 cases of osteo-arthritis, are shown in Table II. It is evident that the results in the cases treated by the small and medium doses are not significant when compared with the control group, the value of $p$ in each group being more than $0 \cdot 05$. With the larger dose $(C)$, however, there is definite evidence that the response to treatment was better: 59 out of 102 cases were improved, and 41 of them showed marked improvement. This is statistically significant, the value of $p$ lying between 0.05 and 0.02 .

On review after 6 months and after one year, 98 per cent. ( 57 out of 58 ) and 79 per cent. (41 out of 52) of these groups of cases had maintained the improvement originally noted at 3 months.

It was interesting to observe that the different parts of the spine did not respond equally to treatment. Of 111 cases in this group, the best results were obtained in the dorsal region, in which 69.2 per cent. of the cases showed a marked improvement. In the cervical region, marked improvement was obtained in 45.8 per cent., but the response in the lumbar region was poor, only $21 \cdot 6$ per cent.

The age of the patient, the duration of the disease, and the extent of the radiological changes had no apparent influence on the therapeutic results. Increase in the range of movement and improvement in function generally accompanied the improvement in pain, unless gross mechanical obstruction was present.

TABLE II

RESULTS AT THREE MONTHS

\begin{tabular}{|c|c|c|c|c|c|c|c|c|}
\hline \multirow{2}{*}{\multicolumn{2}{|c|}{ Diagnosis }} & \multirow{2}{*}{ Dosage } & \multirow{2}{*}{$\begin{array}{c}\text { Number } \\
\text { of } \\
\text { Cases }\end{array}$} & \multicolumn{3}{|c|}{ Improvement in Degree of Pain } & \multirow{2}{*}{$p$} & \multirow{2}{*}{$\begin{array}{l}\text { Percentage } \\
\text { Improved }\end{array}$} \\
\hline & & & & Nil & Slight & Marked & & \\
\hline \multirow{4}{*}{\multicolumn{2}{|c|}{ Osteo-Arthritis (429) }} & A & 89 & 54 & 12 & 23 & $0 \cdot 50>p>0 \cdot 30$ & $50 \cdot 5$ \\
\hline & & B & 182 & 88 & 35 & 59 & $0 \cdot 10>p>0.05$ & $51 \cdot 6$ \\
\hline & & $\mathrm{C}$ & 102 & 43 & 18 & 41 & $0.05>p>0.02$ & $57 \cdot 8$ \\
\hline & & Control & 56 & 35 & 9 & 12 & - & $37 \cdot 5$ \\
\hline \multirow{4}{*}{\multicolumn{2}{|c|}{$\begin{array}{c}\text { Rheumatoid } \\
\text { Arthritis } \\
\text { (257) }\end{array}$}} & A & 61 & 37 & 13 & 11 & $0 \cdot 50>p>0 \cdot 30$ & $39 \cdot 3$ \\
\hline & & B & 70 & 42 & 13 & 15 & $0.50>p>0.30$ & $40 \cdot 0$ \\
\hline & & $\mathrm{C}$ & 76 & 40 & 14 & 22 & $0.10>p \quad 0.05$ & $47 \cdot 3$ \\
\hline & & Control & 50 & 35 & 3 & 12 & - & $30 \cdot 0$ \\
\hline \multirow{9}{*}{$\begin{array}{l}\text { Ankylosing } \\
\text { Spondylitis } \\
\text { (102) }\end{array}$} & \multirow{5}{*}{ Spine } & $\mathbf{A}$ & 14 & 5 & 2 & 7 & $0 \cdot 20>p>0 \cdot 10$ & $64 \cdot 0$ \\
\hline & & B & 17 & 2 & 2 & 13 & $0.10>p>0.05$ & $88 \cdot 0$ \\
\hline & & $\mathrm{C}$ & 19 & 1 & 1 & 17 & $0.02>p>0.01$ & $95 \cdot 0$ \\
\hline & & L.V.T. & 11 & 6 & 2 & 3 & $0.70>p \quad 0.50$ & $45 \cdot 0$ \\
\hline & & Control & 9 & 5 & 0 & 4 & - & $44 \cdot 0$ \\
\hline & \multirow{4}{*}{ Other Sites } & A & 7 & 1 & 2 & 4 & - & - \\
\hline & & B & 11 & 0 & 2 & 9 & - & - \\
\hline & & $\mathrm{C}$ & 9 & 0 & 1 & 8 & - & - \\
\hline & & Control & 5 & 2 & 2 & 1 & - & - \\
\hline
\end{tabular}


In the treatment groups (B) and (C) 91 cases were re-examined radiologically at the end of 6 months. There was no evidence of any obvious changes in 84 cases, and in seven the appearances had deteriorated slightly.

Of cases with symmetrical joints equally involved, 92 received different doses to each joint. Comparison of the results showed that the higher doses (B) and (C) were nearly twice as effective as the smaller dose and the control group combined.

Rheumatoid Arthritis.-The results obtained in the rheumatoid group were disappointing (Table II). It must be pointed out that the majority of the cases treated were in the reactive stage and showed radiological evidence of secondary osteo-arthritic changes.

There were 257 cases in this group, and the results obtained with each dose were not significant when compared with those obtained in the control group, the value of $p$ in each being more than 0.05 . The response to the larger dose (C) was slightly better than that of the small and medium doses. It is possible that the osteo-arthritic element in these cases may have influenced the results.

An opportunity to compare the response of symmetrical joints given different doses was possible in seventy cases. In 53 of those receiving two different dosages the response was equal in both joints. In the remaining seventeen cases given the same dose, the response was equally irregular.

In four cases who responded favourably to the larger dose the radiological appearances had deteriorated after 6 months. In another fourteen cases who did not respond to treatment, the radiological appearance had remained unchanged. The disease had progressed in six cases but had remained unchanged in thirteen of the control group. This showed that the treatment had no influence on the radiological picture.

Ankylosing Spondylitis.-In this group the response to treatment was more dramatic (Table II). The disease being relatively less common than rheumatoid arthritis and osteo-arthritis, the number of patients we have had the opportunity of treating has been correspondingly smaller.

Of 102 cases on our list, seventy received treatment to the spine, and in the other 32 treatment was directed to other areas. The results obtained in the spinal cases treated by the doses (B) and (C) were excellent, the larger dose (C) being only slightly better than the medium dose (B). The response of the cases in the dosage group (A) was less satisfactory when compared with the controls, and the cases treated by L.V.T. failed to respond altogether.

When the results of the other sites were analysed, the response was also very good with the doses (B) and $(\mathrm{C})$, but slightly better with the bigger dose (Table II).

The relief of pain was usually experienced halfway through the course and reached its maximum a few weeks after completion of treatment. All the cases which improved on the dosages (B) and (C) had maintained their degree of improvement one year later.

When the mean values before treatment of the erythrocyte sedimentation rate, haemoglobin, and body weight of all the spondylitic cases were compared with the mean values at 6 weeks, 3 months, 6 months, and 1 year after treatment, it was found that there was a tendency for the E.S.R. to fall and for the weight to increase steadily (Table III). There was no appreciable change in the haemoglobin level over that period of time. The increase in the E.S.R. immediately after treatment, which has been reported by many authors, was not apparent in this small series.

TABLE III

ANKYLOSING SPONDYLITIS (102 CASES)

Average Erythrocyte Sedimentation Rate, $\mathbf{H b}$, and Bodyweight in Treatment Groups $\mathbf{B}$ and $\mathbf{C}$.

\begin{tabular}{ccccc|c|c}
\hline $\begin{array}{c}\text { Features } \\
\text { Assessed }\end{array}$ & $\begin{array}{c}\text { Before } \\
\text { Treat- } \\
\text { ment }\end{array}$ & $\begin{array}{c}6 \\
\text { weeks }\end{array}$ & $\begin{array}{c}\text { After } \\
\text { months }\end{array}$ & $\begin{array}{c}6 \\
\text { months }\end{array}$ & $\begin{array}{c}1 \\
\text { year }\end{array}$ \\
\hline $\begin{array}{c}\text { E.S.R. (Westergren } \\
\text { mm./hr) }\end{array}$ & $\ldots$ & $55 \cdot 5$ & $49 \cdot 9$ & $52 \cdot 2$ & $44 \cdot 1$ & $35 \cdot 3$ \\
\hline $\begin{array}{c}\text { Haemoglobin (g.) } \ldots \\
\begin{array}{c}\text { Bodyweight } \\
\text { (st. lb.) }\end{array}\end{array}$ & $12 \cdot 2$ & $11 \cdot 6$ & $12 \cdot 1$ & $11 \cdot 6$ & $12 \cdot 2$ \\
\hline
\end{tabular}

Pain was relieved irrespective of the stage of the disease. Increase in mobility of the spine commonly followed relief of pain in cases with minimal radiological changes, but it was not apparent in advanced cases with ligamentous calcification. Of 52 cases re-examined radiologically after 6 months, 44 showed no material change. In six cases the disease had progressed in spite of relief of pain, and improvement in the general condition. In two cases only was there some radiological evidence of improvement.

\section{Conclusion}

No definite explanation of the mechanism whereby $x$ rays affect the tissues and relieve pain has been accepted, and the subject is still controversial. Summarizing the above results, we can definitely state that $x$-ray therapy has a place in the treatment of certain arthritic conditions.

The best results are obtained in the treatment of ankylosing spondylitis. The relief of pain is dramatic and the general condition of the patient tends to 
improve, giving the physician the opportunity of applying other forms of corrective treatment with greater comfort to the patient. In our experience it has appeared that doses larger than 1,500 skin $r$ directed to the whole of the spine and the sacro-iliac joints are not necessary, and that in some cases good results may be obtained with $1,200 \mathrm{r}$. The advantages of this dose are that treatment can be safely repeated in 6 months, if necessary, and the dangers of affecting the skin and marrow are practically nil. Another advantage is that hydrotherapy can be given at the same time without any risk of damage to the skin. Whether the treatment arrests the progress of the disease is a debatable question. A definite opinion can only be reached after a careful and very prolonged follow-up of cases and controls. From our results, however, we can see little evidence so far that deep $x$ ray materially alters the evolution of the disease.

The response of osteo-arthritis to deep $x$-ray therapy is also favourable, and the relief of pain is sometimes dramatic after fairly large doses. Certain cases, however, do not respond at all, and the reason for this is not at present apparent. Dausset and Lucy (1930) observed that cases in whom osteophytic lipping was predominant responded better than those with loss of cartilage, sclerosis, and cystic formation, but we have not been able to confirm this observation.

Our results in the treatment of rheumatoid arthritis have been disappointing. This form of therapy is better reserved for those cases who have failed to respond to other forms of therapy, and in whom one or two joints are holding up the efficient rehabilitation of an otherwise relatively quiescent case. Even under these conditions it is not uncommon to see a joint flare up under the influence of deep $x$ ray. To avoid this, careful selection of relatively quiescent cases is essential, and if irradiation is decided upon a large dose should be given.

In conclusion, deep $x$ ray must only be regarded a local treatment, and the care of the patient on general medical lines must never be neglected. As an adjunct to physiotherapy, hydrotherapy, and orthopaedic measures, we believe that much can be done by radiotherapy in selected cases to ease the patient's pain, improve his well being, and facilitate and accelerate his rehabilitation programme.

\section{Summary}

A total of 788 cases of rheumatic conditionsconsisting of . Osteo-arthritis (429), rheumatoid arthritis (257), and ankylosing spondylitis (102)received high or low voltage deep $x$-ray therapy; a parallel series of cases was used as controls.
The cases of ankylosing spondylitis were found to respond best, both as regards relief of pain and general well-being, but little evidence was seen of improvement in the radiological appearance of the bones. Osteo-arthritis was also favourably affected. The results in rheumatoid arthritis were disappointing, and it appears inadvisable to apply $x$ rays except to selected joints when the disease is quiescent.

Deep $x$-ray treatment is useful, but should only be regarded as an adjuvant to other forms of therapy.

I wish to thank Dr. G. D. Kersley for suggesting this work and for his helpful criticism, assistance, and encouragement. Dr. A. Bradford Hill very kindly co-operated in organizing the statistical planning of the experiment. My thanks are also due to Dr. A. A. Flemming, Consultant Radiotherapist to the Bath Hospital Group, and to his staff for their keen interest and help in carrying out the treatment of the patients.

This work was done during the tenure of a Nuffield Grant, for which I should like to express my gratitude.

\section{REFERENCES}

Dausset, I., and Lucy, J. (1930). Paris méd., 1, 112.

Kuhns, J. G., and Morrison, S. L. (1946). New Engl. J. Med., 235, 399 Sokolow, A. (1897). Fortschr. Röntgenstr., 1, 209. Quoted by Kahlmeter, G. (1930). Brit. J. Actino-ther., 5, 93.

Smyth, C. J., Freyberg, R. H., and Peck, W. S. (1941). J. Amer. med. Ass., 116, 1995.

Stenbeck, ??. ??. (1898). Quoted by Kronenberger, P H. (1945). Med. Bull., Bombay, 13, 45.

\section{Radiothérapie dans l'arthrite RÉSUMÉ}

En tout, 788 cas d'affections rhumatismales, comprenant l'ostéoarthrite (429), l'arthrite rhumatismale (257), et la spondylite ankylosante (102), furent traités par des rayons $X$ profonds de haut ou de bas voltage; une série parallèle servit de témoins.

On trouva que les cas de spondylite ankylosante répondirent le plus favorablement, l'amélioration portant sur la douleur et le bien-être des malades mais non pas sur l'aspect radiologique des os. L'ostéoarthrite aussi fut favorablement influencée. Les résultats dans l'arthrite rhumatismale furent décevants et la radiothérapie ne s'y recommande pas, sauf en cas de certaines articulations lorsque la maladie est à l'état non-évolutif.

Le traitement par des rayons $\mathrm{X}$ profonds est utile à titre adjuvant aux autres mesures thérapeutiques.

\section{Radioterapia en la artritis} SUMARIO

Un total de 788 casos de afecciones reumáticas, consistiendo en osteoartritis (429), artritis reumatoide (257), y espondilitis anquilosante (102), fué tratado con rayos $X$ de alto y de bajo voltaje; una serie paralela de casos sirvió de control.

Los casos de espondilitis anquilosante dieron la mejor respuesta respecto al dolor y al bienestar, pero no se vió mejoría del aspecto radiológico de los huesos. También la osteoartritis respondió favorablemente. En la artritis reumatoide los resultados fueron malos y la radioterapia no parece aconsejable a menos de aplicarla a articulaciones particularmente elegidas durante el período de quietud de la enfermedad.

El tratamiento por rayos $X$ profundos es útil, pero debe considerarse como auxiliar a otros medios terapéuticos. 